DOI: https://doi.org/10.34069/AI/2021.48.12.10

How to Cite:

Fomenko, T., Bilotserkovets, M., Sbruieva, A., Kovalenko, A., \& Bagatska, O. (2021). Social media projects for boosting intercultural communication by means of learning English. Amazonia Investiga, 10(48), 89-96. https://doi.org/10.34069/AI/2021.48.12.10

\title{
Social media projects for boosting intercultural communication by means of learning English
}

\section{Реалізація соціальних медіа просктів для підвищення ефективності міжкультурної комунікації у процесі вивчення англійської мови}

Marina Bilotserkovets ${ }^{32}$ https://orcid.org/0000-0003-4692-3444

Alina Sbruieva ${ }^{33}$ https://orcid.org/0000-0002-1910-0138

Andrij Kovalenko ${ }^{34}$ https://orcid.org/0000-0001-6439-5089

Olena Bagatska ${ }^{35}$ https://orcid.org/0000-0002-4443-1385

\begin{abstract}
The paper is targeted to explore the intensification of communication among culturally diverse students by means of creating social media groups. In frames of the psycholinguistic experiment, Ukrainian and Chinese students were working together at detecting common, similar and distinct features in idioms from the Ukrainian, English and Chinese languages. They intented to decode the phraseological picture of the world of Ukrainian, English and Chinese. Participation in social media group enabled participants' exchanging opinions and ideas in the process of learning English. Such intercultural interaction outlined the national-axiological characteristics of Ukrainian, Chinese and English, their outlook and behavioral patterns. Pedagogical observation and interviews with participants revealed that students, who participated in the social media project, learnt traditions, speech etiquette and social norms of other nations, fostered their English speaking and writing skills. It was noted that democratic, uncritical and open-minded
\end{abstract}

\begin{abstract}
Анотація
Метою статті $є$ дослідження інтенсифікації комунікації серед студентів різних культур шляхом створення груп у соціальних мережах. У рамках психолінгвістичного експерименту українські та китайські студенти разом працювали над виявленням спільних, подібних і відмінних рис ідіом української, англійської та китайської мов. Вони мали намір розшифрувати фразеологічну картину світу української, англійської та китайської мов. Участь у групі в соціальних мережах дозволила учасникам обмінятися думками та ідеями в процесі вивчення англійської мови. Така міжкультурна взаємодія окреслила національно-аксіологічні особливості української, китайської та англійської мов, іхній світогляд і моделі поведінки. Педагогічне спостереження та інтерв'ю 3 учасниками показали, що студенти, які брали участь у проєкті в соціальних мережах, засвоювали традиції, мовленнєвий етикет і соціальні норми інших народів, розвивали свої навички розмовної та писемної англійської мови. Було
\end{abstract}

\footnotetext{
${ }^{31} \mathrm{PhD}$ in Pedagogy, Associate Professor, Foreign Languages Department, Sumy National Agrarian University, Ukraine.

${ }^{32} \mathrm{PhD}$ in Pedagogy, Associate Professor, Foreign Languages Department, Sumy National Agrarian University, Ukraine.

${ }^{33}$ Doctor of Pedagogical Sciences, Professor, Pedagogy Department, Sumy State Pedagogical University, Ukraine.

${ }^{34} \mathrm{PhD}$ in Philology, Associate Professor, English Philology and Liguistic Didactics Department, Sumy State Pedagogical University, Ukraine.

${ }^{35} \mathrm{PhD}$ in Philology, Associate Professor, English Philology and Liguistic Didactics Department, Sumy State Pedagogical University, Ukraine.
} 
style of communication in the social media group allowed participants to build informal cooperation, develop tolerance to fellow students, overcome self-doubt and get motivated to communicate with culturally diverse students.

Keywords: learning English, social media groups, intercultural communication, psycholinguistic study, culturally diverse students.

\section{Introduction}

In the last decades the expansion of new technologies has led to the fact that the ways of interaction between people have changed significantly and the territorial boundaries for communication have practically disappeared. Facebook and Twitter, Viber and WhatsApp, various social networks and instant messengers, blogs and forums have become an integral part of everyday life and have united most of the world's population into a worldwide network (Arndt, 2017).

Accordingly, these changes have affected the educational space - the new generation of students cannot imagine their existence without information and communication technologies. Due to the Internet, students have the opportunity to establish and maintain ties and contacts with their peers in other countries, broaden their horizons, study foreign language culture, traditions and customs through joining numerous social media networks (Bilotserkovets et al., 2021a; Y. Lin et al., 2021). The creation of communities and projects in social networks is an indispensable means of the formation of a real language environment, but it requires from their participants a certain level of linguistic and sociocultural knowledge (Kobzhev et al., 2020).

Currently, the students and educators of Sumy National Agrarian University (SNAU), Ukraine, are oriented towards the students-teachers' mobility joint programs, virtual projects as well, with Chinese higher educational institutions. The mediating language in their intercultural academic dialogue is English. Nevertheless, effective association and constructive dialogue are largely based on the knowledge of the evolution and transformation of cultural and ideological paradigms, which is captured in the conceptual sphere of speakers of a particular ethnic language. Phraseology, as a treasure trove of historical and cultural information, becomes a відзначено, що демократичний, некритичний i відкритий стиль спілкування в групі соціальних мереж дозволив учасникам побудувати неформальну співпрацю, розвинути толерантність до однокурсників, подолати невпевненість у собі та отримати мотивацію до спілкування зі студентами різних культур.

Ключові слова: вивчення англійської мови, групи в соціальних мережах, міжкультурне спілкування, психолінгвістичне дослідження, культурно різноманітні студенти.

certain link of linguistic memory, which accumulates the diachrony of comprehension and the denunciation of reality (Yegorova \& Serzhenko, 2014).

Taking into account the realities of the global lockdown, digital environment was chosen for the creation of a linguistic joint research project as a part of the study of virtual internationalization projects (Kobzhev et al., 2020). The goal of the research is to explore the potential of social networks for the formation of intercultural knowledge of future agrarians and prevention of misunderstanding or possible disruption in their intercultural communication through the study of psycholinguistic features of the Ukrainian, English and Chinese native speakers, engaged in the agricultural sphere. In this regard, the main tasks of the paper are to study the concepts concerning the agricultural crafts, agricultural animals, natural phenomena and analyze their psycholinguistic peculiarities reflected in the Ukrainian, English and Chinese phraseologies; to reveal how the work in the linguistic joint research within a social media group influences the intercultural communication of its participants.

\section{Theoretical Framework}

A social network is an online service, a site that allows people to create social connections, build relationships, distribute information, etc. According to Adobe, the most popular social networks, users of which are native speakers of a wide variety of languages, are Facebook (over 2 billion registered users), YouTube (over 1 billion profiles), WhatsApp, Twitter, Instagram etc. In total, there are more than 5.7 billion accounts in all social networks in the world. Numerous studies of social networks have revealed that by its nature they do not contradict the actual role of the education in the society - on the contrary, 


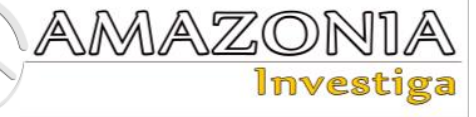

they represent a virtual projection of a significant part of the social and information environment (Silverman, 2012).

The potential of social networks in the field of teaching foreign languages is enormous, since many of them are popular all over the world, and therefore, they provide an opportunity to communicate with representatives of different countries. Academicians worldwide are extensively using social media in teaching foreign languages as an effective means of fostering students' writing, speaking and listening comprehension skills (Yunus \& Salehi, 2012; Che \& Ibrahim, 2018). However, except the lack of linguistic knowledge and skills, that complicate the intercultural communication, there is an issue of diverse psycholinguistic features of interlocutors as the knowledge of cultural and spiritual aspects are necessary for mutual understanding among different peoples in a particular social or professional field (Fomenko et al., 2020). Moreover, the stereotype of the whole nation is based on cultural associations, background knowledge about it, and it is always ethno-culturally and ideologically conditioned (Y. Lin et al., 2021). So, an efficient intercultural dialogue always leads to the investigation of the linguistic and psychological peculiarities of its participants.

Psycholinguistics reflects the process of personal perception through the prism of the mother tongue, taking into account its axiological orientations and, consequently, the differences between various cultures and mentalities, caused by differences in languages (Sapir, 1993). The study of the influence of the language of a particular ethnic group on its worldview and spiritual development was initiated by the scientific works by W. von Humboldt, F. de Saussure, E. Sapir, R. Jacobson, O. Potebnya, G. Deucher, and others, who had stated that the nature of linguistic phenomena should be sought in the human psyche. Thus, different languages influence their bearers' worldview in different ways, not because of what a particular language promotes the thinking of its speakers, but rather because of what it usually obliges them to think (Deucher, 2010, p. 315).

A human language does not only define the cognitive sphere of its bearers, but also the axiological one, because the word, except its basic, object-logical meaning, has an additional, emotional meaning, which is closely related to the subjectively evaluative characteristic of the word. In most languages interpretation, evaluation, and conveyance of the subjective attitudes toward fragments of the national picture of the world are performed by idioms (Tikhonova, 2005). An idiom is an informative unit of language and one of the linguistic universals. It is dually considered, both in linguistic and psychological contexts. In the Ukrainian language the term "idiom" is defined as a product of associative-figurative thinking of a person, verbalized by the language and enshrined in speech (Ukrainian: encyclopedia, 2000). The Chinese stable language expressions are called "chengyu". Their origins are different, but they are all necessary for the determination of a particular style of speech and its emotional intensification (Dzhgun, 2014). British and American scholars use the term "idiom" to define such language anomalies that violate either the rules of grammar or the laws of logic (Shi, 2015).

Almost every idiom is based on a metaphor, that is, belongs to the sphere of similar thinking, creative consciousness of a particular personality and the whole ethnos. Associations distort background knowledge when, in addition to their direct meaning, certain information (individualpsychological, ethno-cultural, etc.) is associated with the word, image (Khayrullina, 2001). Phraseological fund of a language precisely reflects the peculiarities of the perception of its speakers, that is caused by national culture, respectively, analysis of this fund allows to identify the system of symbols and standards of national culture, to study the system of its codes (somatic, zoomorphic, myth-poetic, etc.), specifics of its axiology, etc. (Gudkov, 2003).

\section{Methodology}

A closed community for the study of the phraseology of the Ukrainian, English and Chinese languages was created on the social network Facebook. When choosing a specific social network, the opinion of students was taken in to account: most of them preferred the social network Facebook. Given the variety and types of applications that were built into the Facebook platform, it was the most powerful resource than any other social network in the world. Its facilities enabled the members of the community to participate in multi-stage interactions: conducting discussions, exchanging media files, sending private messages, video conferencing and comment creation, publishing various official data, announcements, documents and topics for discussion (Cheung et al., 2011).

The psycholinguistic study was conducted among Ukrainian students and students from the People's Republic of China, who took Master 
and Postgraduate courses in various specialties at Sumy National Agrarian University. The communication was held in English, the Chinese and the Ukrainian respondents had Pearson's B1 to B2 levels certificates. Besides, the Chinese students learned the basics of Ukrainian for two semesters. Within the limits of the experiment, about 60 informants - Chinese and Ukrainians were involved to explore idioms, covering the conceptual sphere "Agriculture". The study took place from December 2020 to April 2021.

The following set of methods was used to solve the psycholinguistic objectives of the study: the comparative method to find common, similar and distinct features in idioms, belonging to the conceptual sphere of "Agriculture" of the Ukrainian, English and Chinese languages; the descriptive method was used to present the phraseological picture of the world of Ukrainian, English and Chinese. The informants were asked to briefly summarize the essence, the main topic of foreign-language idioms, selected by random (computer) sampling from the previously prepared materials, and to find appropriate idioms in their own language. The correct interpretation of the phraseological expressions was correlated with the understanding of their meaning.

The methods of pedagogical observation and interviews were applied to detect interactions and interrelations among the joint research group. The method of expert evaluation was meant to examine how the participation in the social media group project influenced their skillfulness in intercultural communication.

\section{Results and Discussion}

Psycholinguistic facet of the experiment revealed that the idioms under review were considered to reflect the essential factors of agricultural production in the studied linguistic and ethnic societies, namely: idioms, concerning tools of agricultural labor and attitude to agricultural animals; idioms, describing mythology and archetypes of the Ukrainian, English and Chinese peoples through the natural phenomena.

It was found out, that farming is inseparably linked to auxiliary crafts, the production of primitive peasant tools, agricultural stock, etc., which can tell about simple everyday affairs, for example, in Ukrainian: "Найкраще ремесло плуг і чересло" (the best craft is a plow and a coulter), "Коса любить брусок і сала кусок" (а spit loves a bar and a piece of fat) (Encyclopedia of Ukrainian Studies, 1994); in English: "to call a spade a spade" - to call things by their names (The Free Dictionary (n.d.)). At the same time, the process of metaphorization uses the names of agricultural implements to reveal more complex philosophical phenomena. For example, the cause-and-effect relationship in the Ukrainian language is "Не ставай на граблі, бо дістанеш по чолі" (don't step on a rake because you will get your forehead hit) (Encyclopedia of Ukrainian Studies, 1994); in English - "no root no fruit" - without root there is no flowering (The Free Dictionary (n.d.)); the law of counteraction: in the Ukrainian language - "Гостра була сокира, та на сук наскочила" (the ax was sharp, but it got blunt because of a snag" (Encyclopedia of Ukrainian Studies, 1994); In Chinese, the idiom 疑人偷斧 - to suspect people of ax theft - is used to describe those who, by ignoring facts, rely on subjective assumptions (Chinese-tools (n.d.))

But the main tool for farmers is a plow. This is reflected in phraseology. In the Ukrainian language, the concept of "plow" is a part of many idioms, for example, “держатися плуга" (to hold the plow) meaning to be engaged in agricultural work (Encyclopedia of Ukrainian Studies, 1994). The analogy is an English idiom "to follow the plow" (The Free Dictionary (n.d.)). But in the Ukrainian language this concept has a much deeper symbolic meaning. In people's perception of the earth, it is a woman, a mother, and plowing and sowing symbolizes impregnation, so in folk songs the phrase "there is no one to go to the plow" stands for: there is no one to love a girl (Plaviuk, 1946).

Since prehistoric times, agrarian societies had been closely associated with the world of animals, which were both helpers and feeders of peasants, symbolizing diligence and honesty, for example, as described in Ukrainian sayings: "I тварина розумна, дарма, що не говорить” (and an animal is smart, just does not talk), "Пошануй худобу раз, а вона тебе десять раз пошанує” (honor cattle once, and it will honor you ten times) (Encyclopedia of Ukrainian Studies, 1994).

The Chinese have long done field work by means of buffaloes, like the Ukrainians who plowed with oxen. In the traditional Chinese and Ukrainian cultures, cattle symbolizes wealth, diligence of those who conscientiously or voluntarily carry the burden of hard work: in Ukrainian - "Працює, як віл" (works as an ox), "I чорна корова біле молоко дає" (and a black cow delivers white milk), "Правити вола" (to demand an ox) (Plaviuk, 1946); in Chinese, 像牛 


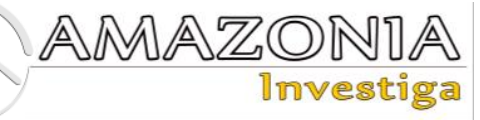

一樣 強壯 means as strong as a cow (Chinesetools (n.d.)). In Great Britain horses had mainly been used in plowing since ancient times, so the concept "horse" symbolizes victory over the difficulties in the British culture, as well as the hard work: "as strong as a horse" (The Free Dictionary (n.d.)).

In the Ukrainian agricultural conceptual sphere, the concept "horse" also symbolizes heavy, aweinspiring, work, which is reflected in the statements: “Люблю Сивка за звичай: хоч крекче, та везе" (I love a horse Sivko for the custom: cry, but work); "Сип коневі мішком не ходитимеш пішком!" (feed well a horse from a sack - you will not walk!) (Encyclopedia of Ukrainian Studies, 1994).

In the Chinese agrarian conceptual sphere, the concept "horse" has a different connotation. So, the idiom 马到成 功 - when horses arrive means easy and fast success from the very beginning. The idiom 指鹿为马 to point to a deer, but to call it a horse, means to deliberately mislead someone by calling white black. The saying 博樂評馬 - Bo Lee judges on horses (Deng \& Liu, 2007) is used to praise those who are well-versed in talent. An interesting analogue is found in English - "from the horse's mouth", which means: to learn certain information from the most competent person in a certain field (The Free Dictionary (n.d.)).

Comparing and identifying the behavior and life of animals with human ones caused many figurative meanings, which are reflected, for example, in the Ukrainian expressions: "Працюй, як коняка, а їж, як собака" (work as a horse and eat as a dog), "У Сірка очей позичати" (to lend eyes from a dog Sirko) (Plaviuk, 1946). The British herdsmen lifestyle is cogitated in the phrase "put out to pasture", which until the 19th century was exclusively used for animals, now describes human life - to force a person to quit his job because of a respectable age (The Free Dictionary (n.d.)).

The next group of idioms, which vividly traces the archetypes and myths of a particular ethnic group, describes a variety of natural phenomena. For a long time, a peasant observed nature, listened to and looked at its manifestations and seemed to consult with it as a living being (Encyclopedia of Ukrainian Studies, 1994). In this group of idioms in the Ukrainian language the influence of ancient pagan beliefs is represented, and the central place is given to the personification of ancient gods: the sun: "Зимове сонце, як удовине серце" (winter sun, as a widow's heart), stars and the moon: "Гарно і при місяцю, коли сонця немає" (it is good even under the moon, if there is not the sun), "З неба зорі хвата, а під носом не бачить" (the one, who catches stars from the sky, but does not see under own nose), the wind: "Верхове галуззя вітри ломлять" (upper branches are broken by the wind), "Посієш вітер - пожнеш бурю" (sow the wind - reap a storm); the rain "Від дощу під борону не сховаєшся" (уоu cannot hide from the rain under the harrow), etc. (Plaviuk, 1946).

Idioms with concepts that embody natural phenomena echoing with paganism were also found in English, among them, the concept "the sun" - "One cloud is enough to eclipse all the sun", little things can ruin the impression; "Make hay while the sun shines" - that is, take the opportunity when it is given to you; the concept "the moon" - "Once in a blue moon", something that happens very rarely; the concept "rain" "As right as rain", feeling good and full of strength; the concept "thunder" - "Steal my thunder", which means that someone distracts attention from another person (The Free Dictionary (n.d.)).

Idioms with mythologies embodied in concepts with the meaning of natural phenomena are also found in Chinese, including the concepts "rain", “sunlight”- 農民希望下雨，步行者希望陽 光，眾神猶豫不決 - a peasant hopes for rain, a traveler relies on sunlight, and gods doubt; “moon”- 從海底獲取月亮 - to get the moon from the seabed, it is spoken in a situation where a person wants to achieve the impossible (Chinese-tools (n.d.))

But most Chinese idioms reflect the ideals of the traditional Confucian philosophy, Taoism, and Buddhism. Here are the aphorisms of the founder of Taoism, Lao Tzu (3rd century BC), who emphasized the nobility of peasant labor and compared agriculture with education, art and philosophy: 在計劃一年 時, 種植玉米。在 規劃十年 時 時時 計劃 生活, 培訓和教育 人員 時 - When planning for the year, grow grain. When planning for decades, plant trees. When planning for life, train and educate people (Deng \& Liu, 2007). And his other world-famous aphorism, which became a proverb: 一棵 巨大 的 樹從一個 小小的幼苗中長出來; 一個 9 層的平台從一堆土地上升起; 千里之旅 從第一步開始 - A huge tree, which is difficult to grasp with your hands, grows from a tiny sprout; a nine-story platform rises from the pile of land; a journey of a thousand lees begins with the first step (Deng \& Liu, 2007). 
Thus, this experiment realistically showed the psycholinguistic peculiarities the Ukrainian, English and Chinese idioms, that outlined the national-axiological characteristics of the concept sphere "Agriculture". The participants of the research had encoded phraseological meanings of a certain linguistic-ethnic groups's psyche and images of an extralinguistic nature, its outlook and behavioral patterns.

The pedagogical facet of the experiment was realized through the observation over the activities of students in the course of their activities on the Facebook group, interviews with them to acquire if the work within the social media group was psychologically comfortable and contributed to the fostering of their intercultural skills. Summing up the outcomes of the interviews, the authors revealed that the research work in the social media group was auspicious in the following ways:

- it provided students' acquaintance with culture, speech etiquette, social norms and patterns of behavior of culturally diverse people ( $85 \%$ respondents);

- it promoted the assimilation and active consolidation of terminological vocabulary, the most significant grammatical and syntactic phenomena characteristic of the target language (93\% respondents);

- it developed the ability to hear and understand ideas of culturally diverse background (98\% respondents);

- it contributed to the formation of productive types of speech activity, of writing skills in particular (96\% respondents). It is essential, as writing traditionally receives much less attention in the learning process, despite the fact, that today its importance is constantly growing due to the spread of various social networks and messengers (Bilotserkovets et al., 2021b);

- it allowed students to learn in practice various strategies of speech behavior of culturally diverse people ( $85 \%$ respondents), as participation in the project enables their getting "an algorithm for meeting and communicating with peers from other countries in social networks" (Kostikova et al., 2019).

Since social networks provided feedback, this kind of communication contributed to the formation of persuasion skills, argumentation of one's point of view, adequate response, predicting the response of interlocutors $(84 \%)$, etc., because the system of discursive dominants of the mental space of personal effectiveness is formed due to the concretized attitudes of the general self-attitude to success, which stimulates the activity-communicative needs of the recipients (Y. Lin et al., 2021). At the same time, communication in the social media community presented higher demands not only for the level of proficiency in a target language, but also for the content of the message, increasing the degree of awareness and personal responsibility of the author (C.-H. Lin et al., 2016).

Another beneficial effect of using social networks in the educational process is the cohesion of the research group. At the beginning of the experiment, the students-participants did not know each other and educators and felt certain alienation. But the communication within the social network group, due to its democratic, uncritical and open-minded features, allowed participants to quickly build informal cooperation style (93\% respondents). Participants of the experiment demonstrated a high level of tolerance to mistakes and difficulties of "fellow students", and a willingness to help. It happened, because "own" community performed the function of a "support group" that helped to overcome self-doubt, motivated not to quit the participation in the experiment (Gerhart, 2017).

Thus, the students of culturally diverse background were helping each other at scientific work on eliminating linguistic and psychological barriers that had complicated their intercultural communication.

\section{Conclusions}

Thus, the experiment proved that the linguistic representation of the concept sphere "Agriculture" is based on the cultural and historical experience of a nation, is unique and peculiar, not only reflecting its axiological essence for a particular ethnic group, but also shaping its worldview and influencing behavioral patterns. The differences found in the perception of foreign-language idioms by the students participating in the study were explained by different geographical and historical factors that had influenced the formation and development of the Ukrainian, English and Chinese ethnic groups. Found analogies and common features in the perception of foreign-language idioms are based on the dialectical unity of the National and the Universal, since there is every unique cultural identity coexists with universal.

The application of social media group allowed the creation of conditions as close as possible to 


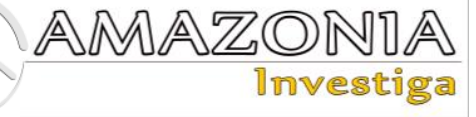

real speech communication in English (in the absence of a natural language environment), facilitation of the language improvement and increasing the motivational aspect of the target language acquisition. We consider the achievements of this study to be essential for deepening international cooperation in higher education, research and production, since understanding the worldviews of foreign partners contributes to the correct interpretation of events occurring in a particular situation in a target language environment, and prevents the misunderstanding in the process of intercultural communication.

\section{Bibliographic references}

Arndt, H.L. (2017). The Role of Online Media in 21st Century Language Learning. Connected Life 2017: Digital Inequalities. Oxford Internet Institute. Retrieved from https://connectedlife.oii.ox.ac.uk/the-role-ofonline-media-in-21st-century-languagelearning/

Bilotserkovets, M., Fomenko, T., Gubina, O., Klochkova, T., Lytvynko, O., Boichenko, M., \& Lazareva, O. (2021b). Fostering Media Literacy Skills in the EFL Virtual Classroom: A Case Study in the COVID-19 Lockdown Period. International Journal of Learning, Teaching and Educational Research, 20(2), 251-269. doi:10.26803/ijlter.20.2.14

Bilotserkovets, M., Fomenko, T., Kobzhev, A., Berestok, O., Shcherbyna, Y., Krekoten, O., \& Kurinnyi, A. (2021a). Dual Nature of Students' Knowledge Formation in the Pandemic Period: Pedagogical and Psychological Aspects. Revista Romaneasca pentru Educatie Multidimensionala, 13(3), 246-261. Doi: 10.18662/rrem/13.3/450

Che, C.R.I.B., \& Ibrahim, W. (2018). Social Media Tools for Informal Language Learning: A Comprehensive Theoretical Framework. Asian Social Science, 14(4), 46-50. doi: 10.5539/ass.v14n4p46

Cheung, C.M.K., Chiu, P.Y., \& Lee, M.K.O. (2011). Online Social Networks: Why Do Students Use Facebook? Computers in Human Behavior, 27(4), 1337-1343. Doi: 10.1016/j.chb.2010.07.028

Chinese-tools (n.d.). Chengyu stories, chinese idioms. Retrieved from https://www.chinesetools.com/chinese/chengyu

Deng, F., \& Liu, L. (2007). A Handbook of Chinese Idioms. Beijing: Peking University Press.

Deucher, G. (2010). Through the Language Glass: Why the World Looks Different in
Other Languages. New York: Metropolitan Books/Henry Holt and Co.

Dzhgun, N.M. (2014). Idioms as a part of Chinese language stylistical lexicology. Linguistic researches, 38, 10-14. Retrieved from http://oaji.net/articles/2014/9181416382567.pdf

Encyclopedia of Ukrainian Studies. (1994). In V. Kubiiovych (Ed.). Vol. 3. Lviv: Molode zhyttia.

Fomenko, T., Bilotserkovets, M., Klochkova, T., Statsenko, O., Sbruieva, A., Kozlova, O., \& Kozlov, D. (2020). Overcoming Barriers in Intercultural Communication: A Case Study on Agricultural Idioms in English, Ukrainian and Chinese. Academic Journal of Interdisciplinary Studies, 9(6), 157-166. Doi: 10.36941/ajis-2020-0120

Gerhart, N. (2017). Technology addiction: How social network sites impact our lives. Informing Science: The International Journal of an Emerging Transdiscipline, 20, 179-194. Doi: $10.28945 / 3851$

Gudkov, D. (2003). Theory and practice of intercultural communication. Moscow: Gnosis.

Khayrullina, R.Kh. (2001). Phraseological picture of the world: from worldview to worldview. Ufa: Publishing house BSPU.

Kobzhev, A., Bilotserkovets, M., Fomenko, T., Gubina, O., Berestok, O., \& Shcherbyna, Y. (2020). Measurement and Assessment of Virtual Internationalization Outcomes in Higher Agrarian Education. Postmodern Openings, 11(1Supl1), 78-92. Doi: 10.18662/po/11.1sup1/124

Kostikova, I., Miasoiedova, S., Razumenko, T., Chernenko, A., \& Pochuieva, O. (2019). Teaching English speaking for FCE: using Facebook as a tool of instructional practice. Amazonia Investiga, 8(22), 719-727. Retrieved from https://amazoniainvestiga.info/index.php/am azonia/article/view/825

Lin, C.-H., Warschauer, M., \& Blake, R. (2016). Language learning through social networks: Perceptions and reality. Language Learning \& Technology, 20(1), 124-147. Retrieved from

https://scholarspace.manoa.hawaii.edu/bitstr eam/10125/44449/1/20_01_linwarschauerbl ake.pdf

Lin, Y., Karabulatova, I.S., Shirobokov, A.N., Bakhus, A.O., \& Lobanova, E.N. (2021). Cognitive distortions in the reflection of civic identity in China: on the material of Russianlanguage media of East and Western. Amazonia Investiga, 10(44), 115-125. doi: 10.34069/AI/2021.44.08.11 
Plaviuk, V. (1946). Proverbs, or Ukrainian Folklore Philosophy. Edmonton: Alberta. Retrieved from https://diasporiana.org.ua/wpcontent/uploads/books/7784/file.pdf

Sapir, E. (1993). Communication. Selected works on linguistic and cultural studies. Moscow: Progress-Univers.

Shi, W.J. (2015). Comparison and Contrast Between English and Chinese Idioms from Cultural Connotation Perspective. Studies in Literature and Language, 10(1), 102-113. Doi: $10.3968 / 6338$

Silverman, M. (2012). How Higher Education Uses Social Media. Mashable. Retrieved from

https://mashable.com/2012/02/03/higher-

education-social-media

The Free Dictionary (n.d.). Idioms and phrases.

Retrieved

from

https://idioms.thefreedictionary.com
Tikhonova, O. (2005). The phenomenon of phraseological enantiosemies (emotional evaluation of an idiom). Chinese civilization: tradition and modernity, 91-94. Retrieved from

http://dspace.nbuv.gov.ua/bitstream/handle/1 23456789/31238/13-

Tikhonova.pdf?sequence $=1$

Ukrainian: encyclopedia. (2000). In V. Rusanivskyi \& O. Taranenko (Eds.). Kyiv: Ukrainian Encyclopedia named after M. P. Bazhan.

Yegorova, O.I., \& Serzhenko, G.V. (2014). Mythology in phraseological reflexion: problems and coding and decoding. Philological treatises, 6(2), 25-30. (In Ukranian)

Yunus, M.M., \& Salehi, H. (2012). The Effectiveness of Facebook Groups on Teaching and Improving Writing: Students' Perceptions. Journal of Education and Information Technologies, 1(6), 87-96. 